\title{
SEMANTIC FEATURES OF ONOMASTIC LEXICON IN THE CONTEMPORARY FICTIONAL DISCOURSE (BASED ON THE NOVELS «A GAME OF THRONES» BY GEORGE R. R. MARTIN)
}

Nazarenko O. V., lecturer at the department of Germanic philology, Sumy State University,

2 Rimsky-Korsakov St., Sumy, 40007, Ukraine,

ORCID ID: https://orcid.org/0000-0002-4134-1894

E-mail: o.nazarenko@gf.sumdu.edu.ua

Velykodna A., student,

E-mail: avelykodna@gmail.com

The article deals with the semantic features of onomastic lexicon in contemporary fictional discourse. It is based on the novels "The Game of Thrones» by George R. R. Martin. In this study, considerable attention is paid to the problem of the determination of onomastic lexicon and its significance in shaping a broad panorama of fictional reality. The analysis was carried out to determine the main tools used to deprive the fictional work of an automated and standardized form. It is determined that proper names are used to single out a particular detail of the character's image: personality traits, profession, social status, etc. The semantic and expressive features of the onomastic vocabulary in the fiction literature, as well as its role in the author's accent on the problems of a writing are analyzed. It has been established that the onomastic lexicon is a tool for expressing the emotional and value component of the image by the author, helping to create an additional conceptual context.

Keywords: onomastic lexicon, fictional discourse, semantic features, literary detail. https://doi.org/10.21272/Ftrk.2018.10(4)-7

Fiction literature always differs by its specificity and authenticity. The proper nouns have a great influence on the ideas of a writer and its embodiment. The author creates a separate world, fills it with life and content through the onomastic lexicon. With the help of different proper names which the author uses in his book, the process of direct acquaintance with characters becomes more convenient. The readers have the ability to figure out the real nature of the main characters even before the evolution of the plot (of course, in the form of some guesses). It is the cognitive component of the proper nouns that provides further evolution of the plot and the characters' actions. Onomastic researches demonstrate that the ways and methods of the proper nouns creating may be different. Their meaning, structure and semantic content depend on a number of conditions: historical, geographical, sociocultural or political.

The relevance of our research is that proper names are an integral part of the fiction text. They not only perform the nominative function, but also carry an additional semantic meaning. The research of semantic peculiarities of onomastic lexicon in fictional literature will help to classify it into groups and analyze the sources of its formation.

The object of the research is onomastic lexicon as the literary detail in shaping a broad panorama of fictional reality. The subject is semantic features of onomastic lexicon which are represented by series of novels «A Game of Thrones» by George R. R. Martin.

The aim of the investigation is to determine semantic peculiarities of onomastic lexicon in the contemporary fictional discourse.

The main tasks are:

1. To investigate the essence of onomastic lexicon and its role in the contemporary fictional discourse.

(C) Nazarenko O. V., Velykodna A., 2018 
2. To analyze semantic features of onomastic lexicon on the material of «A Game of Thrones» by George R. R. Martin.

In the Oxford English Dictionary such a meaning of onomastic lexicon can be found: «lexicon of (especially personal) proper names» [8]. Due to Rutkiewicz-Hanczewska: «connotations are usually not included in a lexical definition» [7, p.171]. Thus onomastic lexicon is one of the tools for making a character image more expressive and emphatic. It can mirror a social status of a person or the territorial geographical and political conditions.

The history of literary discourse is quite ancient. Its main feature is the emphasis, principally on the form of communication through which content is transmitted. In the process of ordinary communication, the meaning always stands in the first place and the methods of its expression go second.

When writing a fiction text, the author sets himself the task of destroying the automatism of ordinary communication and standard perception of information. He needs to force the reader to pay attention to the main issues and analyze the text critically. The attention of the reader is attached to the details for that purpose. Onomastic lexicon in the fiction text is one of the types of the literary detail [2, p. 46]. It helps to make the text fresh, unlike what the reader's mind perceived before reading. That is what makes the text multivalued. The author does not endeavor to make his text similar to a manual for a household appliance or dry citation of the law. The fiction genre allows to create a structure consisting of many layers. Someone will go through the surface; another will try to penetrate deeper.

While creating a logically completed and structured fictional world, it is extremely important for the author of fiction literature to pay attention to proper names. These are images of characters, names of geographical objects and sociopolitical phenomena. The text will look volumetric and panoramic, if proper names are not a simple set of sounds, but they carry an additional hidden meaning. It may be a characteristic of the type of human activity, profession or an emphasis on a certain character trait [3, p. 114] (for example, the name Stark in the novel is a manifestation of extraordinary strength, courage and bravery).

"A game of thrones», which the author has been creating for more than two decades, immerses the reader in a fictional world with a logically complete structure. The author builds several storylines, telling about dynastic wars for power over the Westeros continent, which is quite similar to Europe in the Early Middle Ages. But it is quite impossible to draw a complete analogy with our world, because all the geographical locations, the names of characters and even of the kingdoms are fictional.

When analyzing the onomastic content of the work, the author's deep and thoughtful work with the selection of a lexicon can be traced. The majority of all proper names in the book have a connotative meaning. During the selection of an appropriate proper name for the characterization of a person, the author draws attention primarily to the structure of the word that distinguishes the kind of transmitted emotions. In addition, the nature and combination of onyms depend predominantly on the social views of the author and the culture of the world in a particular epoch as a whole.

The author paid attention to the names of main characters. The using of certain proper names was fully studied by the philologist Schetinin. He describes the categories of onyms and distinguishes neutral and descriptive proper names among them [18]. The first category includes such names that are just typical for certain country, century or social class. They don't have a hidden semantic meaning. As for the second category it includes names that are used for transmitting the additional connotative meaning. In some cases, it just highlights the main features of the character behavior or marks his/ her profession or preferences. The majority of proper names in the novel are descriptive. Author has used different sources and approaches for creating such onyms.

Jon Snow, whose role in the novel is principal, was given maybe the broadest portrait with the help of his proper name. In general, his name is a reference of a typical English image - John Doe - a way of designating the unknown person. For example, a patient who is brought unconscious and without documents is recorded in a hospital as «John». In is 
meant to be a claim - «I am nobody ... or I just look like nobody and I am unknown for the majority of people». He is an illegitimate child of the Lord Stark and has no right to borrow a throne of his famous father. Jon also cannot pretend for the estate of Stark House. The attention should also be paid to his second name «Snow». It was used to highlight the position of the boy in a family. "Dogs were equally divided between the children, only because Jon deliberately abandoned his puppy. Jon stepped aside for the newborn Reckon, because he understood that he was not like the others. The boy is a bearer of the surname Snow that was received by all the bastards born in the north of Westeros...» [10]. He was an albino in the Stark dynasty. No one except his father took him into account in solving some family problems. His position forced him to recruit to the Night's Watch of the Wall. And here we have another symbolic meaning of the name Snow. The Wall was the place on the North of the country with constant frosts and snowfalls. He was born to live in painful coldness to expiate the sins of his parents.

The attention should also be paid to the image of Arya Stark is a specifically described character. Some investigators say that the name is a premise to the ancient Aryans, which inhabited Europe in ancient times. Others associate it with the Greek god of war - Ares. In any case this name can be treated in the only one way. The girl in the novel is very brave and strong. "Little Aria struck John with her sword, and the girl even managed to hurt him...» [10]. From her childhood she practices sword-fighting with her brothers and participates in the battles.

The image of Sansa Stark is also shown very clearly through her name. As we know prefix «san-» reminds to the names of saints, especially martyrs. Most likely, the complexity of the Sansa's fate was destined by the author in advance. There is one more, quite a conspiracy interpretation - the name is similar to the French prefix «sans» «without», and this may mean that the character is destined always remain without something that she loves, that is very important for her. At the beginning of this novel Sansa Stark has everything for the perfect life: she is meant to become a wife of a prince. Her future is clear and light, but one by one all people who were the dearest for Sansa die. She is like a black widow who should stay away from friends and relatives to guarantee a normal life for them. "Sansa's cry was like Septa Mordane as they went far down the stairs. They were going to take away all that was dear to her heart, including the court and her prince» [10].

One of the sons of Eddard Stark was named Robb. And it is a very thin and almost invisible difference for readers between Robert and Robb. It is just the same, but in reality Eddard Stark gave this name to his son in honor of the comrade - the King Robert. The name was intentionally shortened to show the honor to a present king and to highlight his originality and uniqueness. In addition, Rob also became a king in one of parts of a novel and it is interesting to reveal that his reign was also short, just if it is inferior. "All that could be said about Robb Stark was that he had rather courage than a sound mind. He was still too young. I'd hoped that if he saw our left collapse, he might plunge into the gap, eager for a rout» [10].

One of the brightest characters of this book is Cersei. The author used not a simple association, but an allusion to the Ancient Greek myths. Almost everyone knows a story about an evil sorceress and a cunning temptress. This descriptive information is very appropriate for the Queen. She always manipulates with people, plots against them and is ready to kill everyone who will try to prevent her. «You cannot stay a middle course, when you strive to lead in this game of thrones. There is only one way out: to submit or to be submitted...» [10]. A devil with the angel face is the real nature of Cersei.

It should be said that only the minority of onyms opens its nature on the first pages of the novel. Most of proper names also have the hidden importance that reveals only in the second or even third book of the series. Sansa Stark is just one of the examples of this phenomenon, because without reading all the series and without a deep analysis of her character it is difficult to draw parallels between the image of martyr and Sansa. 
Thus, it can be summarized that proper names with an additional semantic meaning are a tool for transmitting the emotionality and value of the image. They help to create an additional conceptual context, setting the reader to the desired perception of specific information. When the reader sees onomastic lexicon for the first time, he can already form a certain image of the character in his head. Sometimes it works even at a stage when the storyline has not yet developed. Sometimes a proper name does not have a clear connotative coloring. In this case, the author allows the reader to speculate about the meaning of the name of a particular character, without depriving him of his own point of view about semantic content. This is what helps the fiction text to remain multifaceted and, as it was mentioned earlier, multi-layered.

In this fiction novel, the author focuses the reader's attention on a such kind of onomastic vocabulary as the names of the characters of the novel. Some of them are neutral and used because of their typicality for the era and situation described in the novel. But most of them are descriptive. They are used by the author to give the character a direct or indirect characterization.

Practical value of the research is in a detailed study of the features of the onomastic lexicon in the future and an analysis of its influence on the perception of a fiction text by the reading audience. We believe that it is important for the development of fiction discourse to trace the tendency of onomastic lexicon using in modern fiction literature: how they are formed and in which cases the use of proper names is not sufficient to form a complete image of the main character.

\section{СЕМАНТИЧНІ ОСОБЛИВОСТІ ОНОМАСТИЧНОГО ЛЕКСИКОНУ В СУЧАСНОМУ ФЕНТЕЗІЙНОМУ ДИСКУРСІ \\ (НА МАТЕРІАЛІ РОМАНІВ ДЖОРДЖА Р. Р. МАРТІНА «ГРА ПРЕСТОЛІВ»)}

Назаренко О. В., викладач кафедри германської філологї, Сумський державний університет, вул. Римського-Корсакова, 2, Суми, 40007, Украӥна

https://orcid.org/0000-0002-4134-1894

E-mail:o.nazarenko@gf.sumdu.edu.ua

Великодна А. I., студентка,

E-mail: avelykodna@gmail.com

У статті розглянуто семантичні особливості ономастичного лексикону в сучасному фентезійному дискурсі. За основу були взяті романи Джсрджа Р. Р. Мартіна «Гра престолів». У даному дослідженні значна увага приділяється проблемі детерміначії ономастичної лексики та ї̈ ролі в прочесі формування широкої панорами фентезійної реальності. Проведено аналіз з метою визначення основних засобів, щзо використовуються для позбавлення фентезійного твору автоматизованого та стандартизованого вигляду. Фентезійний дискурс практично не розглядається науковиями як окремий вид літератури при семантичному аналізі ономастичного лексикону. Між тим, можна виділити конкретні особливості зазначеного жанру, серед яких вагоме місие займає створення логічно завершеної та структурованоі реальності та значна увага до деталей. Визначено, що саме власні назви застосовуються для виділення окремої деталі в образі персонажа: риси характеру, професії, соиіального стану тошо. Пізнавальний компонент ономастичного лексикону забезпечує логічну еволючію фентезійного сюжету. Проаналізовано семантичні та експресивні особливості онімів у художній літературі, а також їх роль у акцентуванні автором проблематики фентезійного твору. Встановлено, шо ономастичний лексикон $є$ інструментом для вираження автором емоційної та иіннісної складової образу, допомагаючи створити додатковий кониептуальний контекст. Використання власних назв сприяє внесенню у текст елементу новизни, наданню фентезійному дискурсу багатозначності та багатошаровості. Оніми виконують додаткову дидактичну функиію, спонукаючи читача до критичного аналізу тексту та акцентування уваги на основних проблемних питаннях. Лінгвістичному дослідженню ономастичного лексикону присвячено велику кількість робіт вітчизняних та зарубіжних дослідників, але попри це питання формування та семантичного наповнення власних назв недостатньо повно висвітлене на сьогоднішній день. Проведене дослідження дозволяє виявити основні властивості впливу ономастичного лексикону на сприйняття фентезійного твору читачем та всебічне розкриття образу персонажа.

Ключові слова: ономастичний лексикон, фентезійний дискурс, семантичні особливості, художня деталь. 


\section{СЕМАНТИЧЕСКИЕ ОСОБЕННОСТИ ОНОМАСТИЧЕСКОГО ЛЕКСИКОНА В СОВРЕМЕННОМ ФЭНТЕЗИЙНОМ ДИСКУРСЕ \\ (НА МАТЕРИАЛЕ РОМАНОВ ДЖОРДЖА Р. Р. МАРТИНА «ИГРА ПРЕСТОЛОВ»)}

Назаренко Е. В., преподаватель кафедры германской филологии

https://orcid.org/0000-0002-4134-1894

E-mail:o.nazarenko@gf.sumdu.edu.ua

Великодная А. И., студентка

E-mail: avelykodna@gmail.com

Сумский государственный университет,

ул. Римского-Корсакова, 2, Сумы, Сумская область, 40007, Украина

В статье рассмотрены семантические особенности ономастической лексики в современном фэнтезийном дискурсе. За основу были взяты романы Дюжорджа Р. Р. Мартина «Игра престолов». В данном исследовании значительное внимание уделяется проблеме детерминации ономастической лексики и ее роли в прочессе формирования широкой панорамы фэнтезийной реальности. Проведен анализ с иелью определения основных средств, используемых для лишения фэнтезийного произведения автоматизированного и стандартизированного вида. Определено, что имена собственные используются для выделения отдельной детали в образе персонажа: черты характера, профессии, социального положения $и$ m. д. Проанализированы семантические и экспрессивные особенности онимов в художественной литературе, а также их роль в акиентировании автором проблематики фэнтезийного произведения. Установлено, что ономастический лексикон является инструментом для выражения автором эмоциональной и ценностной составляющей образа, помогая создать дополнительный концептуальный контекст.

Ключевые слова: ономастический лексикон, фэнтезийный дискурс, семантические особенности, художественная деталь.

\section{СПИСОК ВИКОРИСТАНИХ ДЖЕРЕЛ}

1. Карпенко О.Ю. Проблематика когнітивної ономастики. - Одеса : Астропринт, 2006. - 326 с.

2. Марчук О.В. Власні назви у фентезійних творах: класифікація антропонімів / О.В. Марчук // Науковий вісник Міжнародного гуманітарного університету. Серія: «Філологія». - Одеса: Міжнародний гуманітарний університет, 2017. - Випуск 26. - С.46-47

3. Назаренко О.В. Поліаспектність власних імен в англомовному казковому дискурсі та їх комунікативна спрямованість / О.В. Назаренко, А.А. Ракітіна // Філологічні трактати. - 2014. - Т.6, № 1. - С. 114-117.

4. Щетинин Л.М. Слова, имена, вещи: Очерки об именах / Леонид Михайлович Щетинин. - Ростов н/Д. : Изд-во Ростовского ун-та, 1966. - 222 с.

5. Ojārs Bušs. Some Theoretical Aspects of the Translation of Proper NamesNames and Their Environment [Електронний ресурс] / Proceedings of the 25th International Congress of Onomastic Sciences, Glasgow, August 2014. Vol. 4. Theory and Methodology. Socio-onomastics. Carole Hough and Daria Izdebska (eds). Режим доступу : https://www.gla.ac.uk/media/media_576598_en.pdf. - (13.10.2018).

6. Rachael Hamilton, Ellen Bramwell, Carole Hough. Mapping Metaphor with the Historical Thesaurus: A New Resource for Investigating Metaphor in Names. Names and Their Environment [Електронний ресурс] Proceedings of the 25th International Congress of Onomastic Sciences, Glasgow, August 2014. Vol. 4. Theory and Methodology. Socio-onomastics. Carole Hough and Daria Izdebska (eds). - Режим доступу : https://www.gla.ac.uk/media/media_576598_en.pdf. - (13.10.2018).

7. Rutkiewicz-Hanczewska, Małgorzata (Poland) Semantics of Proper Names. The Structure of the Mental Lexicon of Proper Names [Електронний pecypc] / Proceedings of the 25th International Congress of Onomastic Sciences, Glasgow, August 2014. Vol. 4. Theory and Methodology. Socio-onomastics. Carole Hough and Daria Izdebska (eds). - Режим доступу : https://www.gla.ac.uk/media/media_576598_en.pdf. (13.10.2018).

8. The Oxford English Dictionary [Електронний ресурс] - Режим доступу: https://en.oxforddictionaries.com/(13.10.2018)

9. Webster's New World Dictionary of the American Languages / Michael Agnes [Електронний ресурс] / Webster's New World College Dictionary, 2000. - 559 p. - Режим доступу: http://www.merriamwebster.com/dictionary - (13.10.2018).

10. George R.R. Martin. A Game of Thrones [Електронний ресурс] / George R.R. Martin. - 1996. - Режим доступу: https://novel12.com/241092/a-game-of-thrones.htm. - (13.10.2018).

11. George R.R. Martin. A Dance with Dragons [Електронний ресурс] / George R.R. Martin. - 2011. - Режим доступу: http://hotnovels.net/244130-a-dance-with-dragons.html. - (13.10.2018).

\section{REFERENCES}

1. Karpenko O. Yu. Problematyka kognityvnoii onomastyky. Odesa : Astroprynt, 2006. - 326 p.

2. Marchuk O.V. Vlasni nazvy u fentezijnykh tvorakh: klasyfikatsiia antroponimiv. Naukovyi visnyk Mizhnarodnoho humanitarnoho universytetu. Seriia: «Filolohiia». Odesa: Mizhnarodnyi humanitarnyi universytet, 2017. Vol. 26. P. 46-47.

3. Nazarenko O.V., Rakitina A. A. (2014). Poliaspektnist` vlasnykh imen v anhlomovnomu kazkovomu dyskursi ta yich komunikatyvna spriamovanist` [Polyaspects of Proper Names in English Fairy Tale Discourse and 
Their Communicative Directivity]. Filolohichni traktaty. 2014. Vol. 6, No. 1. P. 114-117. URL:

http://tractatus.sumdu.edu.ua/en/nazarenko-o-v-rakitina-a-a-poliaspektnist-vlasnih-imen-v-anglomovnomukazkovomu-diskursi-ta-yih-komunikativna-spryamovanist/

4. Schetinin. L. M. Slova, imena, veschi: Ocherki ob imenah. Rostov n/D. : Izd-vo Rostovskogo un-ta, 1966. $222 \mathrm{~s}$

5. Ojārs Bušs. Some Theoretical Aspects of the Translation of Proper NamesNames and Their Environment [Електронний ресурс] / Proceedings of the 25th International Congress of Onomastic Sciences, Glasgow, August 2014. Vol. 4. Theory and Methodology. Socio-onomastics. Carole Hough and Daria Izdebska (eds). Режим доступу : https://www.gla.ac.uk/media/media_576598_en.pdf. - (13.10.2018).

6. Rachael Hamilton, Ellen Bramwell, Carole Hough. Mapping Metaphor with the Historical Thesaurus: A New Resource for Investigating Metaphor in Names. Names and Their Environment. Proceedings of the 25th International Congress of Onomastic Sciences, Glasgow, August 2014. Vol. 4. Theory and Methodology. Socio-onomastics. Carole Hough and Daria Izdebska (eds). - URL https://www.gla.ac.uk/media/media 576598 en.pdf. - (13.10.2018).

7. Rutkiewicz-Hanczewska, Małgorzata (Poland) Semantics of Proper Names. The Structure of the Menta Lexicon of Proper Names. Proceedings of the 25th International Congress of Onomastic Sciences, Glasgow, August 2014. Vol. 4. Theory and Methodology. Socio-onomastics. Carole Hough and Daria Izdebska (eds). URL : https://www.gla.ac.uk/media/media 576598 en.pdf. - (13.10.2018).

8. The Oxford English Dictionary . - URL: https://en.oxforddictionaries.com/. - (13.10.2018)

9. Webster's New World Dictionary of the American Languages (2000). Michael Agnes. Webster's New World College Dictionary, 2000. 559 p. - URL: http://www.merriam-webster.com/dictionary. - (13.10.2018).

10. George R. R. Martin. A Game of Thrones. 1996. - URL: https://novel12.com/241092/a-game-of-thrones.htm. - (13.10.2018).

11. George R. R. Martin. A Dance with Dragons. 2011. - URL: http://hotnovels.net/244130-a-dance-withdragons.html. - (13.10.2018)

Received: 26 October, 2018 